\title{
The influence of mass media and political attitudes on students' political participation in the 2020 regent election at SMA Negeri 2 Raha
}

\author{
Harry Fajar Maulana a,1,* \\ ${ }^{a}$ Universitas Muhammadiyah Buton, Jl. Betoambari, Lanto, Batupoar, Kota Bau-Bau, Sulawesi Tenggara 93724 \\ ${ }^{1}$ harryfajarmaulana@gmail.com*; \\ * corresponding author
}

\begin{tabular}{ll}
\hline & ABSTRACT \\
& $\begin{array}{l}\text { Purpose of this study is to explain the influence of mass media and } \\
\text { political attitudes on students' political participation in the } 2020 \text { regent } \\
\text { election at SMA Negeri } 2 \text { Raha, Muna Regency. The method used in }\end{array}$ \\
Article history & this research is associative quantitative research with ex post facto \\
Received $09-11-2021$ & descriptive approach. The research sample is 26 respondents. Data \\
Revised 10-11-2021 & collection techniques using questionnaires and data analysis techniques \\
Accepted $11-11-2021$ & using regression. Based on the results of the analysis and hypothesis \\
& testing, it shows that there is an influence of mass media and political \\
Keywords & attitudes on student political participation in the 2020 regent election at \\
Mass Media & SMA Negeri 2 Raha Muna Regency of $58.8 \%$, therefore students must \\
Political Participation & always be given directions in every election. so that students participate \\
Political Attitudes & in elections.
\end{tabular}

This is an open access article under the CC-BY-SA license.

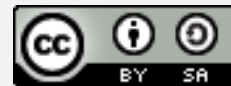

\section{Introduction}

Indonesia is a country that adheres to a democratic system, and the conditions of society are heterogeneous. One of the characteristics of a democratic system is political participation. Political participation is the activity of a person or group of people to actively participate in political life, among others by electing a state leader directly or indirectly and influencing government policy (“Cap. A Crit. Polit. Econ.," 2017).

One form of political participation is the participation of the public or citizens in general elections (Pemilu). Election is the will of the people or the desire of the people so that there is a change for the better through the election of the people's representatives, the President and regional heads (Zuhro, 2019).

\section{Theorotocal Framework}

\section{a) The Factors Affecting Participation}

According to King et al., (2003) that participation in society is influenced by many factors. Factors that influence a person's tendency to participate, namely:

\section{Age Age}

factor is a factor that influences a person's attitude towards existing community activities. Those from the middle and upper age group with a more stable moral attachment to societal values and norms tended to participate more than those from other age groups. 


\section{Gender}

In the culture of various nations it is said that basically the place of women in many societies the role of women is primarily to take care of the household, but over time the value of the role of women has shifted due to the participation process. This participation occurs when everyone can put forward views, discuss the subject matter, raise objections against other people's wishes or against what they say (Roles \& Identity, 1999).

\section{Indirect}

Participation Participation that occurs when an individual delegates his / her right to participate to others. movement for emancipation and better women's education.

\section{Education}

Education is one of the absolute conditions for participation. Education is considered to be able to influence a person's attitude in life towards their environment, an attitude that is necessary for the improvement of the welfare of the entire community (Ingleby, 2012).

\section{Work and Income}

These cannot be separated from each other because a person's job will determine how much income he will get. A good job and income that is sufficient for daily needs can encourage a person to participate in community activities. To participate in an activity, it must be supported by a wellestablished economic atmosphere.

\section{Length of stay.}

The length of time a person lives in a certain environment and his experience interacting with that environment will affect one's participation. The longer he lives in a certain environment, the sense of belonging to the environment tends to be more visible in his large participation in each environmental activity (Bayram \& Şanc1, 2019).

In the implementation of the Election, there are first-time voters who participate in or have the right to vote to participate in the implementation of the legislative elections, the President or regional heads. Chapter IV article 19 paragraph 1 and 2 as well as article 20 states that what is meant by first-time voters are Indonesian citizens who on election or voting day are Indonesian citizens who are 17 years of age and or more or already or have been married who have the right to vote, and previously did not include voters because of the provisions of the Election Law. In fact, every time a Presidential Election is held, many new voters do not exercise their voting rights on the grounds that there are no changes that are relatively better for their welfare. If apathy and the like are shared by the younger generation who are members of the first-time voters, the future political system will be significantly affected (Leonard, 2019).

The results of interviews with several students at SMA N 2 Raha who had become first-time voters during the 2020 Presidential Election, they said that they chose the President based on suggestions from their parents, peers, and the influence of both print and electronic media, while according to some students who did not participate in politics in the 2020 Presidential Election, they gave the reason that according to them there was no real change in the government system for a better direction after the Election was held, they also thought that the presidential election was just a formality and the leaders only made promises not to realize it. In addition, another thing that affects the political participation of these students is the absence of socialization about the Election by the KPU (General Election Commission) in schools, which results in lower student knowledge about the Election (Allcott \& Gentzkow, 2017).

\section{b) Understanding Politics}

According to Miriam Budiharjo in social activities through cooperation with other people, besides that it is also an effort to achieve NHKLGXSDQ $\backslash$ DQJ OHELK EDLN' The concept of power struggle is recognized as a struggle involving the interests of society. In this scope, power is 
limited by the ability of a person or group to influence the behavior of other people or groups according to the wishes of the perpetrator.

\section{c) Understanding MassMedia}

Mediamedia definitely influences people's thinking and actions. The media shape public opinion as to where young people carry out strike demonstrations and protest activities. The way that novice voters usually do to participate in elections is by joining a political party in their area, participating in campaign activities, attending political discussions in their region. brought him to a significant change. Media messages do not just happen, but are created and created by the mass media with a specific purpose. According to Apriadi Tamburaka in Arfian the form of objects can be manipulated, seen, heard, read, or talked about along with instruments that are used properly (Viswanath, Ramanadhan, \& Kontos, 2007).

\section{d) Understanding Political}

Attitudesattitudes can be expressed in various forms. If the political attitude is positive, the political behavior that is shown will also be positive. Conversely, if the political attitude shown is negative, then the behavior, according to Secord (Weible, Heikkila, deLeon, \& Sabatier, 2012), defines feelings (affection), thoughts (cognition), and predisposes one's actions (konasi) to an aspect of the surrounding environment. Attitude is a response or regular expression in the form of feelings, thoughts, and predisposes to one's actions towards the state of the surrounding environment. the politics shown are also negative. The positive or negative of a political attitude depends on several things, namely the ideology of the perpetrators of the political attitude, the organization that shows the political attitude, the cultures that live in the environment of the political attitude actors.

\section{e) General Election}

Based on Article 1 paragraph (1) of Law Number 22 Year 2007 regarding implementation general election, hereinafter referred to as election, is a means of exercising people's sovereignty which is carried out directly, publicly, freely, secretly, honestly, and fairly in the unitary state of the Republic of Indonesia based on Pancasila and the Basic Law.

General Electionelections are elections to elect people's representatives who will sit in the seats of the People's Representative Council, Regional Representative Council, Provincial Regional People's Representative Council, and Election Commission. The General Election Commission is an election management institution that is national, permanent, and independent in charge of carrying out elections. Provincial KPU and Regency / Municipal KPU are the organizers of elections in provinces and districts / cities. The work area of the KPU covers the entire territory of the unitary state (Allcott \& Gentzkow, 2017).

\section{Method}

This research is based on the objective of usingdescriptive research ex post facto, namely tracing back to an event or event and then tracing it back to know the factors that can cause the incident, using an associative quantitative approach. Based on this opinion in this study the members of the DPR, DPD and DPRD. Meanwhile, supervision is carried out by Bawaslu (Sugiyono, 2018).

Republic of Indonesia. The KPU carries out its duties continuously and in holding elections, the KPU is free from the influence of any party with regard to the implementation of its duties and powers. KPU is domiciled in the capital city of the Republic of Indonesia, Provincial KPU is domiciled in the capital city of the regency / city. student politics in the 2020 Presidential Election at SMA Negeri 2 Raha. Descriptive method is used, because this method is an appropriate and relevant method for use in this research. Where in this study it is used to describe, explain, and test the influence of media with political attitudes on student political participation in the 2020 regent election at SMA Negeri 2 Raha, Muna Regency (Sugiyono, 2018). 


\section{Results and Discussion}

\section{a) Data Presentation}

Presentation of the influence of mass media and political attitudes on student political participation in the 2020 regent election at SMA Negeri 2 Raha, Muna Regency.

1. The variable of the influence of mass media on student political participation in the 2020 regent election is influential, which means that the more news in the mass media, the higher the student's political participation in the 2020 Regent election.

2. The variable of the influence of political attitudes on students' political participation in the Regent election 2020 is an effect which means that the higher the higher political attitudes political participation of students in the general election in 2020, Regent.

Table 1. frequency distribution of mass media in elections 2020 Regent

\begin{tabular}{|c|c|c|c|c|}
\hline No. & Class Interval & Frequency & Percentage & Category \\
\hline 1. & $14 \pm 18$ & 2 & $7.70 \%$ & Low \\
\hline 2. & $19 \pm 23$ & 12 & $46.15 \%$ & Medium \\
\hline 3. & $24 \pm 27$ & 12 & $46.15 \%$ & High \\
\hline \multicolumn{2}{|c|}{ Total } & 26 & $100 \%$ & \\
\hline
\end{tabular}

Table 2. Frequency distribution of political attitudes in the 2020 Regent election

\begin{tabular}{|c|c|c|c|c|}
\hline. & Class Interval & Frequency & Percentage & Category \\
\hline 1. & $9 \pm 12$ & 1 & $3.84 \%$ & $\begin{array}{c}\text { Less } \\
\text { Influential }\end{array}$ \\
\hline 2. & $13 \pm 16$ & 4 & $15.39 \%$ & $\begin{array}{c}\text { Sufficiently } \\
\text { Influential }\end{array}$ \\
\hline 3. & $17 \pm 20$ & 21 & $80.77 \%$ & $\begin{array}{c}\text { Highly } \\
\text { Influential }\end{array}$ \\
\hline \multicolumn{2}{|c|}{ Total } & 26 & $100 \%$ & \\
\hline
\end{tabular}

\section{Conclusion}

The variable of the influence of mass media on student political participation in the 2020 regent election is influential, which means that the more news in the mass media, the higher the student's political participation in the 2020 Regent election. The variable of the influence of political attitudes on students' political participation in the Regent election 2020 is an effect which means that the higher the higher political attitudes political participation of students in the general election in 2020 Regent.

\section{References}

Allcott, H., \& Gentzkow, M. (2017). Social media and fake news in the 2016 election. Journal of Economic Perspectives. https://doi.org/10.1257/jep.31.2.211

Bayram, B., \& Şancı, E. (2019). Invasive mechanical ventilation in the emergency department. Turkish Journal of Emergency Medicine. https://doi.org/10.1016/j.tjem.2019.03.001

Capital: A Critique of Political Economy. (2017). In Capital: A Critique of Political Economy. https://doi.org/10.4324/9781912282258 
Ingleby, E. (2012). Research methods in education. Professional Development in Education. https://doi.org/10.1080/19415257.2011.643130

King, G., Law, M., King, S., Rosenbaum, P., Kertoy, M. K., \& Young, N. L. (2003). A conceptual model of the factors affecting the recreation and leisure participation of children with disabilities. Physical and Occupational Therapy in Pediatrics. https://doi.org/10.1300/J006v23n01_05

Leonard, J. S. (2019). Politics. In Mark Twain in Context. https://doi.org/10.1017/9781108617208.017

Roles, G., \& Identity, G. (1999). Gender, gender roles, and gender identity. Identity.

Sugiyono. (2018). Metode Penelitian Kombinasi (mixed Methods). In Alfabet.

Viswanath, K., Ramanadhan, S., \& Kontos, E. Z. (2007). Mass media. In Macrosocial Determinants of Population Health. https://doi.org/10.1007/978-0-387-70812-6_13

Weible, C. M., Heikkila, T., deLeon, P., \& Sabatier, P. A. (2012). Understanding and influencing the policy process. Policy Sciences. https://doi.org/10.1007/s11077-011-9143-5

Zuhro, R. S. (2019). Demokrasi dan Pemilu Presiden 2019. Jurnal Penelitian Politik. https://doi.org/10.14203/jpp.v16i1.782 